\title{
"RESIDUAL RIGHTS" ESTABLISHED BY COLLECTIVE BARGAINING IN TELEVISION AND RADIO†
}

\author{
Robert W. GilberT*
}

I

\section{General Nature of Residual Rights}

Millions of dollars annually are being paid to actors, writers, and directors employed in the production of radio transcriptions, television recordings or kinescopes, and television films of various kinds, as so-called "residuals."

The representatives of the talent guilds who administer the collective bargaining contracts requiring the producers, purchasers, and users of such recordings and films to make these rapidly-increasing payments ${ }^{2}$ have adopted the term "residual rights" loosely to describe the class of economic benefits derived by their respective memberships. Various talent guild agreements ${ }^{3}$ governing the use of recorded or filmed material in radio and television normally permit an initial use or cycle of uses in return for basic wages, salaries, or fees by participating talent employees, but call for additional compensation as a condition precedent to subsequent re-use on successive broadcasts or telecasts. ${ }^{*}$

†The author wishes to express his appreciation to John L. Dales, National Executive Sccretary, and Kenneth Thomson, Television Administrator of the Screen Actors Guild (SAG); Nora B. Padway, former Television Administrator of the Writers Guild of America, West (WGA); Claude L. McCue, Executive Secretary, Los Angeles office, American Federation of Television and Radio Artists (AFTRA); Elizabeth Gould, Executive Secretary, Hollywood Local, Radio and Television Directors Guild (RTDG); and Joseph Youngerman, Executive Secretary, Screen Directors Guild (SDG), for their cooperation in supplying rcsearch material used in the preparation of this article.

*A.B. I94I, University of California at Los Angeles; LL.B. 1943, University of California (Berkelcy). Member of the California bar. West Coast counsel for a number of labor unions and guilds in the entertainment field. The author participated, as an attorney, in the establishment of the Hollywood AFL Film Council and the Motion Picture Industry Council. Contributor to legal periodicals on subjects relating to collective bargaining problems.

${ }^{1} \mathrm{~A}$ single talent organization-Screen Actors Guild-reports that it has distributed payments for "residuals" to its individual members amounting to a total of $\$ 3,868,370.06$, during the period from December 1953 through July 1957 .

'The sharp rise in such payments may be illustrated by the following comparative totals derived from Screen Actors Guild reports on monthly collection of "residuals" for films re-used on television:

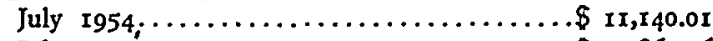

$$
\begin{aligned}
& \text { July } 1955 \ldots \ldots \ldots \ldots \ldots \ldots \ldots \ldots \ldots \ldots \$ 33,862.46 \\
& \text { July } 1956 \ldots \ldots \ldots \ldots \ldots \ldots \ldots \ldots \ldots \ldots \$ 152,048.64 \\
& \text { July } 1957 \ldots \ldots \ldots \ldots \ldots \ldots \ldots \ldots \ldots \ldots 291,599.19
\end{aligned}
$$

${ }^{3}$ The "talent guilds" referred to in this article include: independent guilds (Writers Guild of Amcrica, East; Writers Guild of America, West; Screen Directors Guild), AFL-CiO guilds (Screen Actors Guild; Radio and Television Directors Guild), and an AFL-CIO talent union (American Federation of Television and Radio Artists).

Examples of such agreements and understandings may be found in the following talent guild contracts:

AFTRA 1956-58 Code of Fair Practice for Transcriptions of Broadcasting Purposes. 
The recipients of these "re-use" payments do not, for the most part, possess any proprietary interest, either vested or contingent, in the particular programs or commercial announcements giving rise to this unique form of compensation. They have no apparent common law or statutory right to control the use or re-use of the recorded or filmed material which incorporates the results of their services rendered for the benefit of the producers who employ them. No privity exists between these individual talent employees and many of the purchasers or users of such recordings or films, who often pay "residuals" in lieu of the producer, such as the advertising agency or the national or local sponsor, broadcaster, or distributor of such transcriptions and films.

An individual actor, writer, or director employed in television, radio, or motion pictures may thus become entitled to payment of residuals even without the benefit of any provision in an individual talent contract giving him a legal interest in the receipts, revenue, or profits of the program or commercial material which has been recorded or filmed, and without any property rights created by statute comparable to those conferred upon the author of a literary, dramatic, or musical work under the Copyright Act." $\mathrm{He}$ acquires "residual rights" as a third party beneficiary, under the terms of the collective bargaining agreement between the producer who employs him and the talent guild which represents him in negotiating minimum scales of compensation and other standard conditions of employment, or under the "letters of adherence" from advertising agencies, and "assumption agreements" between the producer and third parties, which are expressly required by that collective bargaining agreement.

Regardless of their source (i.e., whether paid by the original producer of the recording or film, who is the direct employer, or by a subsequent purchaser or user who stands in his place) or the time of payment (i.e., whether paid in advance, shortly after the talent employee actually performs his services, or at a later date, following the specified re-broadcasts or re-uses), residuals represent extra compensation for services rendered by the recipients in the course of their employment, in addition to their basic wages, salaries, or fees.

Although this conclusion seems perfectly obvious-that residuals are, in fact, merely a special type of wage payment based upon the manner and extent of the

AFTRA 1956-58 Code of Fair Practice for Network Television Broadcasting. RTDG x956-58 Basic Minimum Agreement for AM Network Free Lance Directors. RTDG 1956-58 Basic Minimum Agreement for TV Free Lance Directors.

SAG 1955 Television Supplement.

SAG 1955 Codified Contract for Filmed Commercials.

SAG 1955 Industrial Supplement.

SAG 1956 Supplement to Codified Basic Agreement.

SDG 1956 Minimum Basic Agreement.

WGA 1955 Radio Freelance Minimum Basic Agreement.

WGA 1956 Film Television Minimum Basic Agreement.

61 STAT. 65I (1947), I7 U.S.C. I (1956). 
use made of the results of the employee's services-at least one of the talent guilds has .negotiated an express provision in its television film contract declaring that, ${ }^{b}$

Additional compensation for re-runs ... which accrues to the player, as provided ... . herein, shall be considered and treated for all purposes as any other wages due and owing to the player hereunder.

In nearly all cases, whether or not such a contract provision exists, "re-run" or "reuse" payments by the producer or his transferee are treated as "wages" in reporting -and paying taxes to the federal and state governments based upon payrolls.?

The various collective bargaining agreements between the broadcasting networks or film producers and the talent guilds do not use the term "residuals" as such, but speak instead of "additional compensation for re-runs," "re-use fees," "re-play fees," and the like. ${ }^{8}$ The provisions establishing the right of the individual employees to receive these payments are an integral part of the minimum scales set forth in these guild contracts governing "wages," "fees," or "compensation," as the case may be. The contract formula, used to determine the amount of such "minimum additional compensation" for re-runs, re-broadcasts, etc., is usually expressed by way of stipulated percentages of the basic wage rate, salary, or fee applicable to the type of services or period of employment for which the participating talent employee was engaged.

Under certain circumstances, which vary from contract to contract, the producer or purchaser may receive credit for "overscale payments" by applying them against the required minimum payments for residuals.

From a legal standpoint, the importance of recognizing that these residuals are a type of wage payment cannot be stressed too greatly. To cite just a few examples of problems which may arise, beyond the matter of payroll taxes already mentioned, there are (I) the question of the priority accorded wage claims under the bankruptcy statutes; (2) the question of the employer's obligation to refrain from entering into individual contracts of employment which are inconsistent with his obligation to bargain collectively with the labor organization which is the statutory representative

\footnotetext{
'Sec. 27 of the SAG I955 Television Supplement to the Producer-Screen Actors Guild Codified Basic Agreement of 1952.

Sec. XXI of the SAG r955 Codified Contract for Filmed Commercials provides that "Social Security and withholding taxes shall be deducted from all compensation, including use and retuse compensation, paid to all players covered by this contract." (Emphasis added.)

"For example, see the statement construing the California Unemployment Insurance Code in this manner, in News Letter, California Dep't of Employment, No. 3, Jan.-Mar., 1957, p. I.

${ }^{8}$ AFTRA contracts thus refer to "re-use fees" for transcriptions and "re-play fees" for television recordings or kinescopes. RTDG contracts deal with "additional fees" for radio re-broadcasts and "re-play fecs" for television recordings. SAG contracts refer to "additional compensation for re-runs" of television entertainment films; to "reuse payments" or "reuse fees" for filmed commercials; to "payments of additional compensation for re-runs on television" of industrial, educational, and similar nontheatrical motion pictures; and to "payments for re-use" and "re-runs" of photography of "stunts" from theatrical motion pictures incorporated in television films. The current SDG contract sets up a "table of payments" for "subsequent runs" of television films. WGA contracts. prescribe "additional compensation for re-runs" or "re-run payments" for television films and "minimum contingent compensation for a re-use" in the case of recorded radio programs.
} 
of his employees under the labor relations statutes; and (3) the question of exempting labor union activities and agreements designed to secure improved wages and working conditions of employees from the operation of the antitrust laws and restraint of trade statutes.

The appellate courts have not yet passed upon these questions or any of the countless other legal issues of a similar nature which might be mentioned, turning upon the character of residual payments as wages. ${ }^{9}$ It is reasonable to assume, however, that future reported decisions will accept this view as to the nature of residual payments as wages and dispose of litigation which arises hereafter on that ground.

\section{II}

\section{Scope of Bargaining Agreements Establishing Residual Rights}

\section{A. Geographical Scope}

The talent guilds negotiating for residual rights are nationwide labor organizaions, representing employees throughout the United States and Canada, maintaining their national offices either in New York City (AFTRA; RTDG; WGA-East) or Hollywood, California (SAG; SDG: WGA-West), and, in most cases, local or branch offices on the opposite coast. Some of the guilds also have local offices in such key broadcasting centers as Chicago and San Francisco, as well as New York and Hollywood.

Contracts establishing residual rights in recorded network radio or television programs generally define network programs as those normally originating in New York or Los Angeles, and in some cases, also Chicago. Thus, a distinction must be drawn between the point of origination, where the radio and "live" television employees ordinarily perform their services, usually New York or Hollywood, and the areas of re-use, where the recorded or kinescoped program is successively broadcast or telecast. The latter presumably extend to any city within the United States, its territories and possessions, and the Dominion of Canada. ${ }^{10}$

\footnotetext{
-Thus, on March 19, 1957, a trial court in Los Angeles ruled that SAG collective bargaining agreements providing for residual payments based on re-runs of television entertainment films do not on their face constitute a violation of the Sherman Antitrust Law or the California Cartwright Act prohibiting restraints of trade. Screen Actors Guild v. Telemount Pictures, Inc., L. A. Superior Ct. No. 667,323 (unreported). When the Guild filed suit late in 1956 for $\$ 20,000$ in re-run payments allegedly due actors performing in 32 episodes of the "Cowboy G-Man" television film series, which had been run at least six times on television, demanding an accounting by the defendant companies and a court order for inspection of their books and records, Telemount's president reportedly announced that he was going to be "a guinea pig" to test the validity of residual rights under the antitrust laws. The initial ruling by Superior Court Judge Kenneth Chantry was made on demurrer and was not a final determination upon the merits.

${ }^{10}$ As to foreign re-use, the Radio Writers Guild Agreement of 1948, which preceded the WGA 1955 Radio Freelance Minimum Basic Agreement, not only provided "minimum contingent compensation" for "reuse of radio material on radio and/or television" in the United States of America and/or Canada, "including all territories, possessions, dependencies and all territory under the control of either country," but also called for payment of $10 \%$ of the applicable minimum re-use fee when the re-use took place over stations in any one foreign country. Under this former contract, after the $10 \%$ fee was paid or contracted for, "re-use over stations in more than one country" was "subject to individual negotiation between the Employee and the Producer."
} 
The AFTRA Transcription Code, by its terms, is made applicable to "transcriptions made in the United States for use in the United States, its territories and possessions, and Canada." In the case of transcribed spot announcements, as distinguished from programs, re-use fees may vary according to whether they cover "entire country use," i.e. any number of cities and stations in the United States and Canada; the "entire country, other than New York, Chicago, and Los Angeles"; a specified number of cities (such as "one to ten cities" or "one to twenty cities"), other than New York, Chicago, or Los Angeles; or, one or more of the three last-mentioned cities. As to "foreign distribution," the AFTRA Transcription Code specifies that each artist appearing on any transcription sold, leased, or otherwise made available for foreign use shall receive an additional fee equal to the original fee, unless otherwise provided.

Contracts establishing residual rights in television films generally contain express language limiting "additional compensation for re-runs" to telecasting within the United States and Canada and recognizing the producer's right to arrange for unlimited telecasting throughout the rest of the world without payment of residuals. ${ }^{11}$

Extension of residual rights beyond the territorial limits of the United States and Canada has been rather limited to date, but it can be anticipated that this problem will be the subject of future collective bargaining. In addition, various government officials responsible for negotiating international copyright agreements have already expressed considerable interest in this aspect of the future development of residual rights in recordings and films through collective bargaining by the talent guilds of this country.

\section{B. Classes of Employees Covered}

It has already been indicated that re-use payments are being made to the general categories of talent consisting of actors, writers, and directors, but it is necessary to

11 While other Screen Actors Guild contracts only cover actors employed or hired within the territorial limits of the continental United States of America, exclusive of Alaska, SAG's 'Telcvision Supplement also applies (with the exception of union membership requirements) to locations in Canada and studios or production bases in any United States possession or territory. "Television broadcasts outside the United States and Canada" are excluded from the residual rights provisions of SAG's Television and Industrial film agreements.

WGA's television film agreement applies to writers whose contracts are executed within the continental limits of the United States, exclusive of Alaska, regardless of their place of employment. Like SAG's contracts, it confines residuals to television re-runs "in any city in the United States or Canada." On the other hand, the limitation on "additional compensation for theatrical rights" contained in the Screen Writers, Guild Film Television Agreement of 1953, predecessor to the WGA 1956 Film Television Agreement, which excepted "theatrical exhibition" of television films "outside of the United States and Canada" from residuals, has been eliminated. SAG's 1955 Television Supplement still provides that "additional compensation for theatrical rights" need not be paid where a "television motion picture is placed in any theatrical exhibition . . . outside of the United States and Canada."

SAG's 1955 Codified Contract for Filmed Commercials limits Guild recognition and apparently contract coverage as well to employment of actors within the continental United States, exclusive of Alaska, but classifies commercials for purpose of determining re-use fees according to "the number of different cities in which it is telecast during any portion of the applicable use period . . ." without express geographical limitation. 
examine those terms somewhat more critically in order to determine specifically the classes of employees within those broad categories covered by residual rights provisions of the talent guild contracts.

\section{Actors}

AFTRA's Television Code, covering "actors" in "live" television, applies to "all persons engaged as talent, e.g., actors; comedians; masters-of-ceremonies; quiz masters; disc jockeys; singers; dancers; announcers (other than staff duties of staff announcers); sportscasters; specialty acts; ... puppeteers; reporters and analysts ... in the fields of home economics, fashions, farm and rural subjects, and market reports; models; moderators; members of panel where format of program requires such persons to participate generally in entertainment" and "all persons rendering services in the field of news" except for commentators and analysts. (Performers engaged to perform solely as "walk-ons" or "extras" defined as "performers who do not speak any lines whatsoever as individuals" but perform "as part of a group or crowd," as on the legitimate stage, are covered by other provisions but not entitled to receive payment of any re-play fees under the AFTRA Television Code.)

In addition to actors, singers, and announcers, AFTRA's Transcription Code applies as well to "sound effects men," who are entitled to special re-use payments when the results of their services are incorporated in the transcribed program or spot announcement which is being repeated or re-used.

SAG's nontheatrical film contracts generally apply to "all players (including actors, singers, stunt men, and airplane pilots, but excluding extras)"12 as well as off-camera narrators or commentators. SAG's Filmed Commercials Contract covers all such "players" and, more particularly, applies to anyone "who speaks a line or lines of dialogue, whether directly employed for such work, or after being hired as an extra"; "whose face appears silent, alone in a stationary camera shot, and is identified with the product or service"; "whose face appears silent and whose foreground performance illustrates or reacts to the off-camera narration or to the commercial message being given"; or, "whose voice is used "off-camera," except as background crowd noise.

From the foregoing, it may be seen that the actors who have acquired residual rights under these collective bargaining agreements range from lesser performers to stars. Their services may vary anywhere from portaying the principal role in a half hour or one-hour radio or television dramatic program to silently sipping a glass of the sponsor's beer for a few seconds in a short film commercial.

${ }^{12}$ Extra players in motion pictures are expressly excluded from the SAG contract provisions providing residual payments to actors, just as AFTRA excludes "walk-ons and extras" in television recordings. Film extras are represented by a separate organization known as the Screen Extras Guild (SEG) of Hollywood, California, except in the State of New York, where they are covered by a separate SAG New York Extras Agreement. SEG, like AFTRA and SAG, is a branch of the Associated Actors and Artists of America, affiliated with the AFL-CIO, but, for the most part, does not provide in its collective bargaining agreements for residual payments as such. 


\section{Writers}

The WGA Basic Radio Agreement covers "free lance writers (as distinguished from writers on staff)" engaged for the principal purpose of rendering writing services as "employees" for programs broadcast live or by transcription over a national radio network. WGA's Basic Film Television Agreement covers "all writers engaged ... as employees for the purpose of preparing literary material for entertainment portion of motion pictures produced primarily for exhibition over television," excluding "directors, story supervisors, composers, lyricists, or other employees whose participation in writing may be incidental to their bona fide employment in other capacities."13

Generally speaking, the test provided by the WGA agreements for determining whether or not a writer is a covered "employee," rather than an independent contractor, lies in the right of the producer "by contract" to direct the performance of his personal services as a writer.

The WGA collective bargaining agreements creating "residual rights" in writer employees covered thereby are not intended to cover persons who sell or license to the producer their property rights in the use or ownership of literary material without contracting to perform or performing personal services with respect to revision, modification, or changes in such material.

The material contributed by the radio writer entitled to residuals may consist of an original script or an adaptation for all or part of a radio program, or an outline for a radio script. The material contributed by the television film writer entitled to residuals may likewise consist of the final script ("teleplay") or basic story outline ("story").

Under the WGA Basic Film Television Agreement, "additional compensation for re-runs" is paid to "the writer or writers who receive story and teleplay screen credit" for the particular television film. If more than one writer shares a story or teleplay credit, then all of the writers sharing each credit are considered as a unit and participate equally in the aggregate amount of applicable re-run payments. (In the case of a comedy-variety program, the Guild determines the proportions in which the participating writers will share the re-run payments.)

\section{Directors}

The RTDG agreements provide residuals for TV network free lance Directors and AM network free lance Directors, employed to render services on a specified

\footnotetext{
${ }^{18}$ As to "composers" and "Iyricists," it may be noted that this talent group is usually engaged on an independent contractor basis in radio and television, rather than as employees, and is not covered by collective bargaining agreements with the networks or television film producers. See Matter of American Broadeasting Company, and Composers \& Lyricists Guild, II7 N.L.R.B. No. 4 (1957). On the other hand, the experience of the American Society of Composers, Authors and Publishers (ASCAP) and the Songwriters Protective Association (SPA), respectively, in the administration of "performing rights" and "mechanical rights" of popular songwriters under the Copyright Act has been studied by talent guild representatives in developing methods of administering "residual rights" established through collective bargaining.
} 
program or programs, whether or not exclusively, as distinguished from staff directors.

These programs may vary greatly in content, and dramatic programs are but one type. They may include sports shows, but sportscaster programs, news and commentary programs which do not use two or more actors, forums, roundtables, speeches and discussions, and man-on-the-street programs are exempt from the minimum fee requirements of the RTDG agreements.

Screen directors covered by the SDG agreement who receive repayments for subsequent runs of television films are ordinarily engaged to direct the making of dramatic or other entertainment films in the motion picture manner, as distinguished from the methods usually employed in "live" radio and television production.

\section{Kinds of Recordings and Films Affected}

Practically all of the talent guild contracts creating residual rights in the various existing types of recordings and films currently used for radio and television broadcasting purposes reveal the concern of the negotiators with the problem of anticipating technological changes in the mechanical means of reproducing the audio and video portions of broadcast material.

AFTRA's Transcription Code, by its terms, applies to "electrical transcriptions and sound recordings, including audio tape, wire recording, sound tracks, and any other similar devices and other means for audio reproduction ... now or hereafter devised or perfected. ..." Special provisions are made in that agreement for future negotiations with respect to the use of transcription for television, "new or different devices or methods of recording, relaying or broadcasting" or "any contingencies or operations not covered."

AFTRA's I954-56 Network Television Code indicated that it applied to programs originally broadcast either "live" or by recording and defined "recordings" as those made "before or during a broadcast transmission, by electrical transcription, tape recording, wire recording, film, or any other similar or dissimilar method of recording television programs, whether now known or hereafter developed." The 1956$5^{8}$ Network Television Code not only carries that same definition forward in the successor contract, but, in addition, contains a new paragraph entitled "Recorded Programs Covered by Collective Bargaining Agreement." That new provision confirms the terms of a "clarification agreement" entered into under the I $954-56$ Code and declares that the AFTRA contract applies to network television programs

produced or recorded by means of any electronic video equipment (including a combination electronic and motion picture or "slave" camera) used either in connection with live broadcasting or in connection with electronic video recording, whether by means of disc, wire, tape, kinescope, audio tape recorders, video tape recorders, wire recorders, disc recorders, and any other apparatus now or hereafter developed which is used to transmit, transfer or record light or sound for immediate or eventual conversion into electrical energy. (Excluded from the foregoing are programs recorded solely by motion picture camera not in connection with a radio broadcast or a live telecast.) 
The special significance of the language in parentheses just quoted may become apparent when it is recalled that AFTRA was formed by merger of the American Federation of Radio Artists (AFRA) and Television Authority (TVA), a joint bargaining agency originally formed by the "live talent" branches of the Associated Actors and Artists of America (i.e., Actors Equity Association, Chorus Equity Association, American Guild of Variety Artists, American Guild of Musical Artists, and AFRA). This merger into AFTRA took place some time after the National Labor Relations Board granted SAG's request for separate bargaining units for actors in "live" and "filmed" network television programs. ${ }^{14}$

SAG's $195^{6}$ Supplement to its Basic Agreement with the Major Motion Picture Producers and its Television Supplement contain an amendment to the contracts confirming the understanding that

the term "motion pictures" as used herein and in all prior agreements between the parties means and includes and has always meant and included motion pictures, whether made on or by film, tape or otherwise, and whether produced by means of motion picture cameras, electronic cameras or devices, tape devices or any combination of the foregoing or any other means, methods or devices now used or which may hereafter be adopted.

The WGA Basic Radio Agreement applies to programs broadcast "by transcription," and simply refers to the right of the producer to record the writer's material for a permitted use "on tape or otherwise." WGA's Basic Television Film Agreement more elaborately defines a "television film" as that term is used therein to include "the entertainment portion of motion pictures or records, tapes, or other analogous devices, whether now known or hereafter devised for the recordation of visual images produced primarily for exhibition by free television, excepting, for the purposes of this agreement, kinescopes of live television broadcasts."

RTDG's AM Radio Agreement refers to programs "transcribed by technical or electrical means" or re-broadcast "by recording." That guild's TV agreement defines "television programs" to include those "consisting, in whole or in part, of film, tapes, kinescopes and/or recordings, by whatever means." It also contains practically the same language as the AFTRA definition of "Recorded Programs Covered by Collective Bargaining Agreement" quoted above, which includes programs recorded by various kinds of recording devices "or any other apparatus now or hereafter developed" and excludes "programs recorded solely by motion picture camera not in connection with a radio broadcast or a live telecast."

RTDG's television contract includes within the definition of other programs covered by that collective bargaining agreement, shows "such as "You Bet Your Life' over which the guild has previously had jurisdiction." (This is a reference to the Groucho Marx audience participation quiz program, which had been produced in the manner of a live telecast before a battery of motion picture cameras, and thereafter finally edited before being released.)

\footnotetext{
(1951).

${ }^{14}$ Matter of American Broadcasting Company, and Television Authority, 96 N.L.R.B. No. II4
} 
The RTDG agreement, like the AFTRA agreement covering network television programs, reflects the guild's concern for extending coverage within the "gray area" between "live" television and "film" television jurisdiction. In the case of the actors, the jurisdictional divisions are shared between AFTRA and SAG, which are sister branches of the same parent organization within the AFL-CIO. In the case of the directors, the split of "jurisdiction" between the AFL-CIO guild (RTDG)and the independent guild (SDG) is perhaps even more tenuous.

The former jurisdictional division between the Radio Writers Guild and the Screen Writers Guild lessened somewhat when those organizations were succeeded by WGA-East and WGA-West, which now divide jurisdiction along geographical lines, with the Mississippi River as the boundary line, rather than splitting it along technological lines. Both of these affiliated guilds are now co-parties to the same basic agreements for "live" broadcasting and television film production.

It appears that future technological changes in the manner of recording and/or filming radio and television programs may create considerable problems regarding the interpretation and application of the talent guild agreements establishing residual rights, as between the producers and the guilds. Should such difficulties arise, they may or may not become further complicated in some instances by jurisdictional problems in those cases where the existing agreements have been entered into with different guilds representing the same general category of employees in "live" broadcasting and "television films" respectively.

\section{Types of Uses Affected}

Residual payments, generally speaking, are based upon re-use of recordings and films for broadcasting purposes over radio and television networks, as well as local stations. Such re-use may be on a "national," "regional," or "syndicated" basis, as those terms are defined by the particular collective bargaining agreements involved.

Most of the talent guild agreements contain specific provisions dealing with additional fees for "simulcasts," i.e., broadcasts of a single performance of a program by radio and television, whether or not the radio and television broadcasts are made at precisely the same time.

The same material may be otherwise used on both radio and television, as in the case of spot announcements which are transcribed or filmed with accompanying sound track. AFTRA's Transcription Code provides a specific schedule of additional fees for certain kinds of spot announcements which are "used for both radio and TV purposes." On the other hand, SAG's Filmed Commercials Contract only covers "the right to use such commercials in television and for any industrial use where no compensation is received by Producer for such use of the commercial." The SAG contract expressly provides that the use of a commercial in any other entertainment field "shall be the subject of individual bargaining between the Producer and the players involved." 
Different residual agreements cover recordings used to supplement "live" programs, filmed sequences made especially for inclusion in a "live" program, and films produced primarily for nontelevision purposes which are also used on television.

- Residuals are ordinarily required to be paid in connection with re-use in commercial broadcasting and telecasting. Special concessions are contained in a few talent guild agreements with respect to re-uses by the Armed Forces, the United States Department of State, or other government agencies. Screen Actors Guild grants the broadest concession of this type in its Industrial Supplement which waives additional compensation for repeated telecasts of pictures produced for agencies of the United States Government and contains an agreement by SAG to consider applications for similar waivers as to pictures made by or on behalf of nonprofit welfare and public service organizations.

RTDG's Television Network Agreement excepts the syndication of recorded programs to educational television stations from its limitations. However, the Radio and Television Directors Guild reserves the right to negotiate with respect to such use and to halt the exception for the remainder of the contract term if interim negotiations are requested and fail to produce agreement after good faith bargaining.

WGA and SAG agreements establishing residual rights both make clear that they only cover "free television," meaning the exhibition of motion pictures by television where no charge is paid by the viewing audience. WGA has thus expressly reserved the right to negotiate with respect to "paid" or "subscription" television, and SAG has done so by implication. RTDG's network television agreement, in contrast, specifically applies to "closed circuit" programs which are "transmitted to paying audiences."

Both SAG and WGA have provided in their agreements for payment of additional compensation for theatrical exhibition of films produced primarily for exhibition over free television. This special form of residual payment is required by SAG's contract only where such theatrical use takes place in the United States and Canada, whereas WGA's contract applies to world-wide theatrical use of television films.

III

\section{Parties to Residual Rights Agreements}

In addition to the direct signatories to the collective bargaining agreements establishing residual rights, third parties may secure the benefits or assume the obligations created by them with respect to the payment of additional compensation for re-use.

As already mentioned, residual rights do not constitute vested property rights in the strict sense, ${ }^{15}$ but the individual talent employees do apparently acquire a chose in action thereunder comparable to any other wage claim. ${ }^{16}$ Under the general theory

\footnotetext{
${ }^{25}$ Compare $\$$ XXVII of the 1955 Filmed Commercials contract, which provides that "The right of a player to compensation for the use and re-use of a commercial shall be a vested property right and shall not be affected by the expiration of this contract or by any act on the part of the Producer."

${ }^{10}$ The Supreme Court of California recently held in Atkinson v. Superior Court, 49 Cal. 339, 310
} 
of contracts, they are third party beneficiaries, with a legally enforceable right to receive the minimum payments specified in the agreement.

Third party obligations with respect to the payment of residuals, on the other hand, cannot be incurred under these collective bargaining agreements by one who purchases the recordings or films from a signatory producer or otherwise acquires the right to use them in the absence of his express or clearly implied assent thereto.

The contractual restrictions on re-use of the recorded or filmed material by the signatory producers, who are the employer parties to the talent guild contracts, do not automatically bind their successors in interest. (One may say, somewhat waggishly perhaps, that there is no such thing, for example, as a "covenant running with the kinescope.")

In addition to the leading producers of radio and television programs and commercials who negotiate collective bargaining agreements with the guilds ${ }^{17}$ and numerous independent producers who also execute identical or similar contracts, ${ }^{18}$ liability for residual payments may also extend to third parties who step into the signatory producer's shoes, legally speaking, by entering into some form of "assumption agreement."

P.2d 960 (I957), that a disputed claim for accrued and future "re-use payments" by individual employees based upon re-use of theatrical motion pictures on television, pursuant to the terms of collective bargaining agreements between the American Federation of Musicians and the Motion Picture producers, is a chose in action, amounting to an intangible form of personal property. According to this unanimous opinion, the musicians' claims to residuals was a sufficient res to support jurisdiction to grant a preliminary injunction and appoint a receiver as a means of sequestering and ultimately determining title to such funds. The Atkinson case (decided together with the companion case of Anderson v. Superior Court, involving so-called "royalty payments" under the American Federation of Musicians phonograph record trust agreements) arose out of a representative action brought in the Los Angeles Superior Court by twenty-two individual musicians, allegedly on behalf of 2400 American Federation of Musicians members employed in the motion picture industry. Plaintiffs claim that $\$ 1,495,000$ in accrued re-use payments and another $\$ 5,000,000$ in future re-use payments are "additional wages or compensation to the musicians involved" which have been or will be wrongfully diverted to the union's Music Performance Trust Fund unless an injunction is granted and a receiver appointed pendente lite.

${ }^{17}$ The principal national talent guild agreements in radio are negotiated by AFTRA, RTDG, and WGA with the American Broadcasting Company, Columbia Broadcasting System, Mutual Broadcasting System, and the National Broadcasting Company, while the principal signatories to the national "live" television agreements are $A B C, C B S$, and NBC. The principal talent guild agreements covering television films are negotiated by SAG, SDG, and WGA with the Association of Motion Picture Producers, known as the "Majors" (including Columbia Pictures, Metro-Goldwyn-Mayer, Paramount, Republic, Warner Bros., 2oth Century-Fox, RKO, Universal, Allied Artists, and Walt Disney Studios), and the Alliance of Television Film Producers. Separate negotiations are conducted by AFTRA with the transcription companies for its Transcription Code and by SAG with the producers of filmed television commercials for its Codified Contract in that field.

${ }^{18}$ The AFTRA and WGA agreements with the network companies covering "live" programs and their recorded versions specifically contemplate that the network "packager" or "independent contractor" is required to sign, adopt, and conform to the collective bargaining agreement. SAG's Codified Basic Agreement provides that all motion picture producers in the United States "shall be afforded the opportunity of becoming a party to this agreement," and independent producers of television films and other nontheatrical films shown on television who sign the applicable SAG Supplements are by contract "deemed also to have signed the Codified Basic Agreement." Many of the talent guild agreements provide that the signatory producer will cause any subsidiary company owned or controlled by it to sign an identical contract, or that the signature of the parent producing company shail likewise bind its subsidiaries. 
Producers signatory to one of the AFTRA Codes expressly agree therein that they will "abide by, conform to, and be bound by each and every provision" of the other National and Local Codes of Fair Practice.

AFTRA agreements with the networks and transcription companies contemplate that advertising agencies using their facilities will execute "letters of adherence" binding them to all of the terms and conditions of employment specified in the collective bargaining agreement, including those provisions relating to payment of residuals. (WGA's network agreements and SAG's filmed commercial contracts also provide for such letters of adherence from the advertising agencies. The required form for such a letter agreement is set out in detail in each of the respective talent guild contracts, which in most cases call for it to be delivered by the advertising agency directly to the guild or to the signatory producer, with a copy to the guild.)

If the producer sells, transfers, assigns, licenses, or otherwise disposes of its broadcasting or telecasting rights in any recording or film covered by a residual rights agreement, it is almost always provided that the third party purchaser must enter into an "assumption agreement" with the producer, which is made expressly for the benefit of the talent guild and its members. Under these assumption agreements, the third party purchaser generally accepts the obligations of the collective bargaining agreement and specifically agrees to make prompt payment of residuals as a condition to his right to broadcast or telecast the recorded or filmed material thus acquired.

The form of assumption agreement to be required of third party purchasers who thus become liable for payment of residuals is spelled out by each of the talent guild contracts and varies somewhat in detail from one contract to the other. AFTRA's Transcription Code and SAG's Filmed Commercial contract simply call for an assumption clause to be inserted in the producer's contracts with the third parties. AFTRA's Network Television Code requires the producer to secure and deliver a copy of the Code itself executed by the transferee or licensee, together with a signed amendment thereto, acknowledging that the Code will apply to all recordings acquired from others and authorizing the union to take certain steps to secure and enforce payment of residuals by the third party purchaser. RTDG's network television agreement calls for the third party to execute a separate assumption agreement with both the network company and the guild, while most SAG and WGA contracts require delivery of an executed copy of a separate assumption agreement between the producer and the third party purchaser, which recites that the guild and its members are the express beneficiaries, with appropriate rights to pursue residual claims against the "buyer."

Regardless of the form which the particular assumption agreement may take, it almost always provides that the rights of the third party purchaser to use of the recorded or filmed material are subject to and conditioned upon the prompt payment to the talent employees involved of the required additional compensation for re-runs and expressly confers upon the guild the right to secure injunctive relief and damages against the third party purchaser in the event such payments are not made. 
When the producer has obtained the execution and delivery to the guild of the assumption agreement from the third party, the guild normally looks to such purchaser, assignee, or transferee for residual payments, and the liability of the producer to the guild or the talent employees involved for such residuals becomes extinguished.

\section{IV}

Effect of Resmual Rights Agreements Uton Individual Talent Contracts

Like other collective bargaining agreements, talent guild contracts establishing residual rights only set forth a schedule of minimum compensation below which individual contracts of employment may not fall.

Most of the talent guild contracts plainly state that nothing contained therein shall preclude the individual talent employee from bargaining for "better terms" with respect to payment of residuals.

The AFTRA Transcription Code permits the sponsor or producer to be credited with the amount of the artist's compensation in excess of the specified minimum where a definite understanding to that effect is contained in the artist's written or verbal contract of employment. Under the AFTRA Network Television Code, overscale payments in excess of twice the minimum fee may, if consented to by the performer at the time the original engagement was made, be credited toward monies due for re-plays of television recordings.

RTDG's AM Radio agreement permits the overage above the minimum applicable fee to be credited to minimum re-broadcast fees where the director's individual written contract expressly so provides, but the RTDG Television agreement imposes the further restriction that such overage shall not be applied to re-play fees unless the director is paid at least fifty per cent in excess of the applicable minimum fee.

SAG's Television Supplement authorizes the crediting of payments under a player's individual employment contract which gives him "a percentage or other participation in the receipts, revenues or profits of the television motion picture," as against the "minimum additional compensation for re-runs" specified by the guild contract. The SAG Filmed Commercials contract requires that there be a "specific provision in writing to that effect in the player's individual contract of employment" before "over-scale payments" may be credited against re-use fees payable under the guild agreement.

WGA's Film Television agreement permits crediting of amounts received by the writer as a percentage in the proceeds of a television film under his individual employment contract as against the minimum residual payments specified in the guild agreement, but not until the writer has received from all sources an amount equal to twice the applicable minimum compensation.

The foregoing examples of the varying arrangements by which overscale payments may be credited against the specified minimum residual payments required by talent guild agreements are sufficient to indicate that in this respect, as in other 
aspects, the details will vary from contract to contract, but in general, most talent guilds take a similar approach to the problem.

Since each of the guilds represents both talent employees who work regularly at the contract minimums as well as a smaller number of outstanding persons who are able to command much higher compensation and secure individual contracts for their personal services with more favorable terms, the collective bargaining contracts simply place a floor under re-run or re-use payments and permit "stars" or other higher-salaried talent to individually negotiate their own "deals" relating to increased residual payments.

Talent guild agreements allow advance payments for residuals at the time of employment or at any time before the re-use actually takes place, if such an arrangement is expressly agreed to by the talent employee in his individual contract of employment. WGA's Television Film agreement, for example, permits such an arrangement in all cases, but "only such part of the compensation initially paid to the writer as shall exceed twice the applicable minimum compensation may be applied in prepayment of additional compensation for re-runs."

The Screen Actors Guild Television Supplement also allows advance payment of television re-runs where the player's salary is at least double the applicable minimum rate, but expressly prohibits the producer from making any residual payment to a "day player," i.e., a player employed by the day, usually at the contract minimum, "at any time prior to the time of the re-run for which payment is made." Apparently, SAG's theory in negotiating this latter limitation on prepayment of television re-runs is to provide the lower-paid actors.with a regularity of income which would not exist if the producer could buy up their residual rights in advance through individual negotiations.

Most of the talent guild contracts provide "standard forms" of individual employment contracts to be tendered to the individual talent employee, which may be modified to contain more favorable provisions than the collective bargaining agreement, but are otherwise deemed to incorporate the minimum terms and conditions therein prescribed. The individual employee may not effectively waive the benefits of residual rights granted by the talent guild contract without the express consent of the guild itself.

In short, individual contracts of employment may increase or enlarge upon the residual rights established by the talent guild agreements, but only the guild itself, as the exclusive bargaining representative of the employees, may consent to a waiver, reduction, or other modification of such contract rights which would be inconsistent with the minimum requirements of the collective agreement. ${ }^{19}$

\footnotetext{
${ }^{10}$ Atkinson v. Superior Court, 49 Cal. 339, 310 P.2d 960 (1957), supra note 16, raises the issue as to the right of the collective bargaining representative to modify the contract requirements for residual payments to particular employees within the bargaining unit, over their objections, by further negotiations with the producers or employers. In that case, the individual musicians seek to impose a constructive trust in their favor under the theory that the alleged amendatory agreement diverting residual payments to the American Federation of Musicians trust fund, upon the ostensible ground that the
} 


\section{Restrictions on Re-Use Imposed by Residual Rights Agreements}

In the absence of specific limitations imposed by law or by contract, the producers of recorded and filmed material have generally taken the position that they have the unrestricted right to use the same for any purpose, without first obtaining the consent of any of their talent employees who participated in the initial production of such material.

\section{A. Limitations on Type of Use}

The producers of theatrical motion pictures have, since 1929 at least, included a specific provision in the standard form of "free lance" contract used in hiring film actors, recognizing that the rights granted the producer and his successors in interest, to distribute, transmit, exhibit, or otherwise exploit a particular "photoplay" are deemed to include

... motion pictures produced and/or exhibited with sound and voice recording, reproducing and/or transmitting devices, radio devices, and all other improvements and devices, including television, which are now or may hereafter be used in connection with the production and/or exhibition and/or transmission of any present or future kind of motion picture production. (Emphasis added.)

Efforts by individual screen actors to halt the televising of motion pictures originally produced for theatrical purposes, on the theory that this was a different use of their services than contemplated by the terms of their initial engagement, have largely met with defeat in the courts. ${ }^{20}$

In I948, two years after the American Federation of Musicians entered into a collective bargaining agreement with the major motion picture producers which provided that theatrical motion pictures with musical scoring would not be released for television without further agreement of the Musicians' Union, ${ }^{21}$ the Screen Actors Guild entered into another "stop-gap" provision with the major producers. The latter agreement provided that SAG could cancel its basic collective bargaining agreement with any producer, upon sixty days' written notice, if such producer televised or licensed the television of any new motion picture released between August $x$, I948, and May 3I, 1958, except (I) motion pictures made exclusively for "free television,"

individual musicians who rendered services in the particular motion pictures being exhibited on television could not be located, is a breach of the union's duty to protect the interests of all the employees whom it represents. See Ford Motor Co. v. Huffman, 345 U.S. 330, 338 (1953); also Upholsterers' International Union v. Leathercraft Furniture Co., 82 F. Supp. 570, 574 (E.D. Pa. I949).

${ }^{20}$ See Roy Rogers v. Republic Productions, 104 F. Supp. 328 (S.D. Cal. 1952), rev'd, Republic Pietures Corp. v. Rogers, 213 F.2d 662 (gth Cir. 1954), cert. denied, 348 U.S. 858 (I954).

${ }^{22}$ Between 1952 and 1955 , a form of re-use payments was made to employee musicians on a sliding scale, based upon $\$ 25$ per instrumental musician, $\$ 50$ to a leader, $\$ 75$ to an arranger, etc., presumably as additional compensation for their services in theatrical films released to television. After 1955, it appears, all payments for the use of theatrical motion pictures on television were contributed to the AFM Music Performance Trust Fund to be used in presenting "live" concerts by instrumental musicians. throughout the United States and Canada for the promotion of public knowledge and appreciation of nusic, and the "re-use payments" were discontinued. See note 16 supra. 
where no charge is directly paid by the viewing audience; (2) motion pictures televised in theatres or other places where admission is charged; and (3) motion pictures televised as newsreels or trailers. In 1952, SAG's 1948 stop-gap provision restricting the use of theatrical motion pictures on television was carried forward in its Codified Basic Agreement and is still in effect. Motion pictures made exclusively for free television are now covered by SAG's Television Supplement.

AFTRA likewise negotiated a provision in its $19545^{6}$ Network Television Code which prohibited the showing of any kinescope recording in any area where the program was previously carried without the written 'consent of the union, pending the working out of more definite residual arrangements for kinescopes.

The underlying theory advanced by the talent guilds in restricting the right of the producer to use recorded and filmed material for several different uses appears to have been based upon the idea that the talent employee should, as a matter of fairness, receive additional compensation for additional uses of the results of his services. Where agreement has been reached on a formula for payment of additional compensation for a subsidiary use or different type of use, the talent guilds have consistently agreed to removal of the restrictions previously imposed by the contract.

Talent guild agreements have been negotiated waiving existing contract restrictions on the televising of theatrical motion pictures, ${ }^{22}$ and conversely, provisions have been entered into authorizing the theatrical exhibition of television motion pictures. ${ }^{23}$ Agreements have also been negotiated permitting the telecasting of industrial pictures and other similar types of nontheatrical motion pictures not initially made for exhibition on television. ${ }^{24}$ Restrictions on the re-use of kinescope recordings have recently been relaxed when agreement was reached for payment of residuals. ${ }^{25}$

\section{B. Limitations on the Number of Uses}

Talent guild agreements providing for residual payments ordinarily recognize that the recorded or filmed program material may be used once in each city without payment of additional compensation.

If the program material is to be broadcast or telecast more than once, but not more than twice, in any city, it is often said to be in its "second run," and a similar test is applied in determining when a third or succeeding run takes place.

Additional compensation for re-broadcasts or re-runs are generally based upon

${ }^{22}$ See, for example, SAG's so-called "Monogram Agreement" which grants a waiver of the restrictions on televising theatrical motion pictures for a 7 -year period in return for additional payment to cach actor who performed services therein of an amount equal to $15 \%$ of the total salary or other compensation originally paid for his services. This form of agreement does not permit televising of any picture carlier than 3. years after its initial theatrical release, nor apply to paid theater television or "pay television," such as Phonevision or Telemeter, for which a fee is charged the viewer. After the expiration of the 7-year period, an additional payment is required, to be determined by negotiations or arbitration. SAG undertakes in this agreement to secure individual releases from the actors before delivering checks for the $15 \%$ payments to them, but does not waive any rights which the particular actor may have to control the televising of his performance under an individual employment contract or under the right of privacs.

${ }^{28}$ See the SAG and WGA television film agreements.

24 See the SAG Industrial Supplement.

${ }^{25}$ See the AFTRA 1956-58 Network Television Code. 
the total applicable minimum salary for the initial use, so that the contract may call for a full re-payment of such minimum or a portion thereof depending upon the particular schedule of payments.

For example, both the SAG and WGA current television film agreements prescribe the following percentages of the total applicable minimum compensation to be paid for re-runs:

2d Run.........not less than 35 per cent $4^{\text {th }}$ Run.........not less than 25 per cent $3^{d}$ Run......... not less than $3^{\circ}$ per cent 5 th Run......... not less than 25 per cent 6th Run and all additional runs........ a single fee of not less than 25 per cent

AFTRA and RTDG agreements prescribe different percentages for re-plays of television recordings, but apply the same principle under which a downward scale of graduated payments is made for successive re-uses, until payment is made for the last step in the scale which covers all additional re-uses.

\section{Limitations on the Periods of Use}

Residual rights agreements relating to various classes of commercial announcements, such as AFTRA's Transcription Code and SAG's Filmed Commercials Contract, generally recognize that such transcribed or filmed material may be used repeatedly in a specified number of cities for a particular period of time, known as a "cycle," without payment of additional compensation. The designated periods of original use usually consist of thirteen-week or twenty-six-week cycles. Thereafter, additional uses may be continued during equivalent cycles by paying to the talent employees further fees prescribed for re-use on either an unlimited or limited basis.

In addition to the indirect limitation upon the period for re-use of filmed commercials through the requirement of additional payments, SAG's contract directly imposes a maximum period during which a commercial may be used, i.e., eighteen months as to "On Camera" players and $2 \frac{1}{2}$ years as to "Off Camera" players, commencing with the date of first use or with a date six months after completion, whichever date is earlier. This maximum period may be automatically renewed for successive equivalent periods of time, but any player employed in such commercial can terminate the right of renewed use of the commercial by giving the advertising agency or sponsor written notice of his election to do so not less than sixty days prior to the expiration of the original maximum period or any renewal period. The SAG contract itself recognizes that "re-use of a filmed commercial may limit or curtail further employment opportunities for the players appearing in the commercial." The guild contends that the identification of the player with a particular product or service increases proportionately with the continued telecasting of a filmed commercial, so that advertisers and their agencies seldom approve the employment of a player who has become identified with another product or service, especially if it is competitive. Accordingly, the player is given the right to withdraw the commercial from circulation after the maximum use period has elapsed. 


\section{Limitations on Incidental Uses.}

While most talent guild agreements provide that the purchaser, assignee, or transferee of the producer's broadcasting or telecasting rights in the recorded or filmed material must enter into an assumption agreement accepting the obligations of the collective bargaining agreement for payment of residuals, as already discussed, the SAG and WGA television film agreements clearly state that no network, station, sponsor, or advertising agency shall be liable for payment of such additional compensation merely because it uses such material incidentally, when it neither produces nor becomes the owner of the producer's television rights therein.

Residual payments are not usually required where an excerpt from a recorded or filmed television program is used for trailer or promotional purposes.

While, under certain circumstances, talent employees engaged to perform services for the entertainment portion of a program may agree to include the making of program commercials as a part of their services without payment of additional compensation, this is not ordinarily the rule. Additional compensation may also be required for services rendered in making standard noncommercial program openings and closings and other similar material intended for use in several episodes of the same series of programs when the talent employee does not otherwise render services for all of such episodes.

The use of recorded or filmed inserts in "live" programs may call for additional compensation to the talent employees involved, depending upon the particular circumstances and the specific provisions of the applicable guild agreement.

Where previously recorded or filmed material is integrated with other such material so as to make a new or revised program or commercial announcement under circumstances permitted by the talent guild agreement, there will usually remain a requirement that the employees involved continue to receive the applicable re-use payments so long as the altered material is used. Of course, the requirements for payment of residuals do not apply with respect to any employee in connection with any particular re-use if no part of the results of the employee's services is contained in the recording or film as re-used.

No effort has been made by the writer of this article to spell out in detail the numerous restrictions on use and re-use of recorded and filmed material for radio and television broadcasting purposes which appear in the individual talent guild agreements. Such restrictions will vary from guild to guild and from contract form to contract form within the same guild. Moreover, as time passes and experience builds up in negotiating and administering such contracts, it can reasonably be anticipated that these details will be modified.

From the standpoint of analyzing the nature of the problems dealt with by residual rights agreements and the kinds of solutions which have emerged through collective bargaining procedures for dealing with these problems, it is sufficient, perhaps, to make a few general observations. 
First of all, it seems clear that the talent guilds have firmly established by contract their right to impose restrictions on the use and re-use of recorded and filmed material, both as to the purposes or kinds of uses which will be allowed and as to the extent and duration of usage which will be permitted.

Secondly, the talent guilds have secured recognition from the producers of such recorded filmed material that talent employees may sell their services for a limited initial use and require additional compensation when the results of those services are put to a different or repeated use beyond that initial use.

Finally, the talent guilds have secured for the employees represented by them certain defined contingent interests arising from the re-use of such recorded or filmed material in radio and television broadcasting, which may be legally enforced against the producers who directly employ them or against the third party purchasers who expressly assume these obligations for their benefit as a condition of acquiring the producer's radio or television rights, even though such employees have neither been granted any proprietary interest in the recordings or films themselves nor been accorded any separation or reservation of property rights respecting the future use of such material in the various entertainment media. ${ }^{26}$

\section{VI}

\section{Administration and Enforcenient of Residual Rights}

\section{A. Method of Payment}

Most talent guild agreements provide that residual payments shall be made directly to the employees entitled thereto, although the SAG and WGA television film agreements permit delivery of the employees' checks to the guild, which in turn forwards them. ${ }^{27}$

The time for payment of residuals may vary anywhere from ten to eleven days after re-use, as in the network broadcasting contracts (e.g., AFTRA, RTDG, and WGA), or up to six months after the first telecast of the respective television re-run in any city, as in the television film agreements (e.g., SAG and WGA).

The talent guild customarily receives some form of production memorandum or report from the producer containing sufficient information to permit computation of re-use fees for all talent employees concerned who are covered by the guild contract, and thereafter is furnished with re-use reports from the producer or third party

${ }^{30}$ WGA's Basic Film Television Agreement of 1956 provides for "separation of rights," so that certain "reserved rights" may ultimately revert to the writer of a story or teleplay after the passage of specified periods of time, and the producer thereby agrees to give the writer an appropriate assignment under the copyright of all such reserved rights. These provisions relating to literary or dramatic property rights are wholly unrelated to the so-called "residual rights" to additional compensation for re-runs and theatrical exhibition of television films which are the subject of this article.

${ }^{37}$ Delivery of such checks to the guild for forwarding constitutes payment to the employee for the purpose of making timely payments as required by the collective bargaining agreement, but problems have arisen under the California Unemployment Insurance Code in determining the week in which the employee should be deemed to have received "wages" in the form of residuals paid indirectly through the guild. For such purposes, it appears that payment of residuals does not take place until the check is mailed out or delivered to the employee by the guild. 
purchaser disclosing the particular recording or film and the "run" or "re-use" for which the additional payment is being made.

The development of an adequate system of records and reports for the purpose of administering these residual rights agreements is still in the making. Although SAG and WGA contracts require the television film producer to keep or have access to "complete records" showing all cities in which all films subject to those agreements have been telecast and the number of telecasts in each such city, the television stations on which such telecasts were made, and the dates thereof, and to make such records available to the guild for reasonable inspection, both SAG and WGA recognize by contract that there may be an inadvertent failure to comply with the reporting and record-keeping requirements which would not constitute a default or breach of contract on the part of the producer.

It may be anticipated that the existing methods of informal cooperation between the various guilds, producers, advertising agencies, and network companies in exchanging information concerning re-use of recorded and filmed material will eventually lead to a more systematic approach to this phase of the administration of residual rights agreements.

B. Security for Payment of Residuals

AFTRA reserves the right in its Transcription Code to require the posting of an adequate bond, cash, or other security, and further declares that the rights of performers to future compensation for the re-use of transcriptions shall not be affected by any sale, assignment, pledge, hypothecation, or other transfer, or by any attachment, garnishment, bankruptcy, assignment for the benefit of creditors, probate, or any other legal proceeding involving the producer or his successor in interest. The producer's right to re-use any transcription made under that Code is thereby stated to be subject to the condition precedent of the payment of all required fees, so that presumably any person acquiring the producer's rights by voluntary or involuntary assignment will only be permitted to exercise such re-use rights upon payment to AFTRA members of the re-use fees owed to them.

AFTRA's Network Television Code requires the producer's transferee or licensee expressly to acknowledge the union's right to require it to post a bond to insure payment of any re-play fees which may become due with respect to all recordings acquired from others.

SAG likewise reserves the right to demand financial assurance as to the producer's ability to meet its payroll for all actors employed by it, including the execution of written assignments of accounts due and to become due from any purchaser, lessee, licensee, or distributor of television motion pictures produced by it, as its share of the proceeds, in order to secure the prompt payment of residuals.

\section{Enforcement of Residual Rights through Legal Action}

As previously mentioned, the assumption agreements required by most of the residual rights contracts between the talent guilds and the signatory producers spe- 
cifically authorize the guild to obtain injunctive relief and damages against the third party purchaser in the event residual payments are not made as provided in the collective bargaining agreement.

Although California law makes collective bargaining agreements specifically enforceable, just like any other contracts, ${ }^{28}$ SAG has amended its 1955 Television Supplement to emphasize that "the Guild shall be entitled to injunctive relief and damages against Producer, its distributor, or any other person, firm, or corporation which shall violate" the provisions of the contract requiring "prompt payment to the players involved of additional compensation" for re-runs and theatrical exhibition of television motion pictures produced thereunder. ${ }^{29}$

VII

\section{CONCLUSION}

The establishment of residual rights with respect to recorded and filmed material utilized for radio and television broadcasting purposes through collective bargaining is still in the formative stages. Further refinement and elaboration upon the existing contractual arrangements in this field are bound to come with the subsequent reopening of current talent guild agreements for future collective bargaining negotiations on this subject. ${ }^{30}$

In addition to the talent guilds, other labor organizations in the various branches of the radio, television, and motion picture industries are beginning to study the advisability of seeking some form of residual payments on behalf of the employee groups whom they represent.

Technological changes within the radio and television broadcasting field itself will also bring forth numerous problems which will have to be faced by those responsible on both sides of the bargaining table for negotiating and administering existing and future residual rights agreements.

The courts, and perhaps also arbitration tribunals, will be called upon in the years ahead to interpret and apply residual rights of this sort in a wide variety of difficult legal situations.

Residual rights agreements are not yet sufficiently well-established to justify reaching any final conclusions as to their future course, except the rather safe prediction

${ }^{28} \mathrm{CAL}$. LABOR CODE $\$$ II26 declares that "any collective bargaining agreement between an employer and a labor organization shall be enforceable at law or in equity, and a breach of such collective bargaining agreement by any party thereto shall be subject to the same remedies, including injunctive relief, as are available on other contracts in the courts of this State."

${ }^{20}$ SAG's Television Administrator, Kenneth Thomson, reports that of $x 66$ different television series filmed under contract to that guild, residual payments have been made regularly by 157 , only 2 absolute defaults have taken place, and only I lawsuit has been brought to date to enforce collection.

${ }^{30}$ WGA's Basic Film Television Agreement of 1956 provides for such an eventuality by requiring the signatory producers to either grant such more favorable terms to WGA or permit WGA to reopen its contract generally, if at any time during the life of that agreement, which runs until January I5, 1960, the producers shall grant more favorable terms relating to additional compensation for re-runs to cither the Screen Actors Guild or Screen Directors Guild during collective bargaining negotiations. 
that further experience will inevitably bring many changes in the scope and effect of these contracts.

Collective bargaining is always a mercurial process, and there is less reason, perhaps, to expect permanent solutions for problems of this nature in a dynamic industry like radio and television than in-other more static industries. It is, therefore, not surprising that residual rights agreements remain in a transitional state, but only surprising that the general pattern for such agreements has developed so clearly in a very few years. 